Review

\title{
Cystic fibrosis, body composition, and health outcomes: a systematic review
}

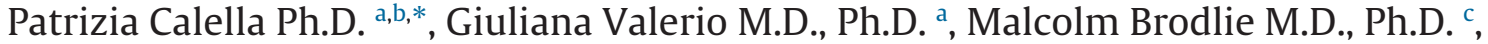 \\ Lorenzo Maria Donini M.D., Ph.D. ${ }^{\mathrm{d}}$, Mario Siervo M.D., Ph.D. ${ }^{\mathrm{b}}$ \\ a Department of Movement Sciences and Wellbeing, Parthenope University, Naples, Italy \\ ${ }^{\mathrm{b}}$ Human Nutrition Research Centre, Institute of Cellular Medicine, Newcastle University, Newcastle on Tyne, United Kingdom \\ ' Institute of Cellular Medicine, Newcastle University and Great North Children's Hospital, Pediatric Respiratory Secretaries, Royal Victoria Infirmary, Newcastle upon Tyne, \\ United Kingdom \\ d Sapienza University of Rome, Department of Experimental Medicine-Medical Pathophysiology, Food Science and Endocrinology Section, Food Science and Human Research \\ Unit, Rome, Italy
}

\section{A R T I C L E I N F O}

\section{Article history:}

Received 10 November 2017

Received in revised form

26 February 2018

Accepted 22 March 2018

\section{Keywords:}

Cystic fibrosis

Pulmonary function

Lean body mass

Fat mass

Disease risk

\section{A B S T R A C T}

Objectives: Patients with cystic fibrosis are characterized by an increased risk of nutrient malabsorption and inflammation, which may influence body composition. We examined the differences in body composition between patients with cystic fibrosis and healthy controls and how body composition differences may impact disease risk and mortality.

Methods: Three different electronic databases (PubMed, Web of Science, and Embase) were used to find articles from inception until March 2017. The search strategy excluded articles that reported data on anthropometric measures only such as body weight, height, or waist circumference. Information on the characteristics of the study populations (e.g., age, sex, body mass index), type of study design, body composition methods, body compartments, and health outcomes was extracted.

Results: Thirty-nine articles were included in the systematic review. The total number of patients with cystic fibrosis and controls that were included in these studies was 1839 and 2178, respectively. Only one study explored the association between body composition and risk of mortality whereas the majority of the studies examined the association between body composition and respiratory function (33\%). Patients with cystic fibrosis had less fat-free mass and bone mineral density compared with the controls and fat-free mass was associated with decreased inspiratory muscle strength.

Conclusions: Patients with cystic fibrosis may be at an increased risk of sarcopenia and osteopenia. The measurement of body composition could improve the assessment of nutritional status and reduce the risk for respiratory and metabolic complications in patients with cystic fibrosis.

(c) 2018 Elsevier Inc. All rights reserved.

\section{Introduction}

Cystic fibrosis (CF) is an inherited disease that is caused by recessive mutations in the cystic fibrosis transmembrane conductance regulator gene, which cause altered transport of chloride, bicarbonate, and sodium ions across the epithelial cell mem-

Sources of support: This work was supported in part by Fondo di sostegno alla ricerca individuale, annualità 2015 e2017, Programma triennale della ricerca dell'Università degli Studi di Napoli Parthenope to Dr. Giuliana Valerio.

Conflicts of interest: The authors declare no conflicts of interest.

* Corresponding author. Tel.: +39 3348393954; fax: + 0815474963.

E-mail address: Patrizia.calella@uniparthenope.it (P. Calella). branes [1]. The phenotypic manifestations of this dysfunction are abnormal fluid transport and accumulation of thick mucus in different organs such as the liver, pancreas, intestines, and lungs [2].

Patients with $\mathrm{CF}$ are affected by a range of respiratory and gastrointestinal problems including airway inflammation and increased susceptibility to repeated infections, exocrine pancreatic insufficiency and malabsorption, and a chronic inflammatory status that leads to general malaise and a poor quality of life [3]. Patients with CF may have a reduced level of physical activity (PA) and increased resting energy expenditure, which is often exacerbated by pulmonary complications, increased fecal energy loss, and reduced food intake that is caused by inflammation-related 
anorexia. All these factors may contribute to the increase in risk of malnutrition [4].

The mechanisms that explain the increase in resting energy expenditure are still unclear and could be associated with the severity of pancreatic insufficiency and lung inflammation [5]. The risk of malnutrition could also be increased by fecal energy losses as a result of malabsorption. The incremental transit of unprocessed food in the intestine may further intensify the malabsorptive syndrome as a consequence of bacterial intestinal overgrowth and low bicarbonate output [6]. The resulting negative energy balance that is derived from a reduced appetite and increased energy needs contributes to the risk of deterioration of the nutritional status of patients with CF [7].

Body composition can be assessed using various methods that provide quantitative and qualitative information on various tissue components such as fat-free mass (FFM), fat mass (FM), total body water (TBW), bone mineral density (BMD), and bone mineral content (BMC). These methods are all characterized by advantages and disadvantages that can affect the precision and accuracy of the body composition assessment, the applicability in clinical or research settings, and most importantly the provision of specific information on body components.

In 2015 the UK CF Trust Registry Report found that $12.4 \%$ of children and adolescents with CF were below the $10^{\text {th }}$ percentile weight-for-age and sex and the median body mass index (BMI) in adults age 18 to $40 \mathrm{y}$ was $22.4 \mathrm{~kg} / \mathrm{m}^{2}$ [8]. The careful monitoring of growth trajectories and nutritional status is a key priority in the multidisciplinary care of patients with CF. The poor nutritional status of patients with $\mathrm{CF}$ is associated with a deterioration of their quality of life and may accelerate the clinical progression of the disease [9]. Several studies have shown a close association between malnutrition and a decline in lung function $[10,11]$.

There is a growing body of literature in support of the importance of the assessment of nutritional status in patients with CF to improve diagnostic and therapeutic health care pathways $[12,13]$. This systematic review aims to examine the differences in body composition between patients with CF and healthy controls and discuss how these differences may impact survival and clinical endpoints such as impaired lung function and recurrent infections.

\section{Methods}

\section{Search strategy}

The systematic review was conducted in accordance with the Preferred Reporting Items for Systematic Reviews and Meta-Analyses guidelines [14]. The PubMed, Web of Science, and Embase databases were searched by one researcher (PC) from their inception to March 2017.

The following terms were included in the search strategy: (cystic fibrosis OR cftr) AND (body composition OR nutritional status); AND (fat mass or fat free mass OR adiposity OR lean body mass OR muscle mass OR hydration OR body water OR body cell mass OR bone mineral content OR bone mineral density OR osteopenia OR osteoporosis). Only articles in the English language and studies that were conducted in humans were selected. In addition, a manual search of the reference lists was carried out to find additional studies.

Two investigators (MS and PC) independently reviewed the titles and abstracts to identify eligible studies and any doubts over eligibility were resolved by discussion until a consensus was reached between the authors.

\section{Inclusion criteria and data extraction}

The inclusion criteria that were applied to this systematic review were: 1 ) Research that was published in the English-language; 2) assessment of body composition in patients with $\mathrm{CF}$; and 3) comparison of the body composition of patients with CF with those of healthy controls. Duplicate publications were excluded from the review. We also excluded studies that evaluated body composition by measuring only weight, height, or waist circumference.

Data from eligible studies were independently extracted using a standardized form. The following information was collected: First author, year of publication, type of study, sample size, description of study population (i.e., age, sex, race, and country of study), method of body composition measurement, description of body composition (i.e., weight, height, BMI, FFM, FM, TBW, BMD, and BMC), pulmonary function (forced expiratory velocity in $1 \mathrm{~s}$ [FEV 1 or percent of predicted values $\left.\left[\mathrm{FEV}_{1} \%\right]\right)$, main aims, and findings of the selected studies.

\section{Study quality assessment}

The quality of the studies was measured using the Downs and Black item checklist [15], which is a recommended instrument by the Cochrane Collaboration for use in observational and non-randomized studies [16]. We omitted seven questions from the original checklist because these items were specific to interventional trials. Two extra items (\#14 and \#15) were added because they reviewed the quality of the methods that were used to evaluate body composition and the body compartments that were analyzed. The final checklist included 15 items with a maximum score of 15 points (range, $0-15$ ) with the higher points indicating superior quality (Supplementary Table S1). The tool assesses quality criteria such as a clear description of the aims, interventions, participants, outcome measurements, and quality of the statistical analyses. Studies were independently appraised by two reviewers (LMD and PC). A cutoff point of nine was adopted in this systematic review to categorize studies as high $(\geq 9)$ or low $(<9)$ quality.

\section{Results}

\section{Search results}

The search of the electronic databases identified 8788 potentially relevant studies. After removing duplicate studies, 1850 studies were initially reviewed on the basis of an assessment of the titles and abstracts against the eligibility criteria. A total of 1523 articles failed to meet the inclusion criteria and were excluded from the review. The remaining 327 full-text articles were assessed for eligibility and 39 studies were included in the final review. Figure 1 summarizes the screening and selection process.

\section{Description and quality of the studies}

Among the 39 included studies, two were longitudinal $[17,18]$ and the remaining 36 studies had a cross-sectional design (Table 1). All studies included a healthy control group. The total number of patients with CF and controls was 1839 and 2178, respectively. The age range of the subjects was different between the studies: Nine studies recruited subjects age $<10$ y $[18,22,40]$ and 10 studies included subjects age $10 \mathrm{y}$ to $20 \mathrm{y}[17,39,49]$ but the majority of the studies were conducted in adult populations (18 studies: age $\geq 20 \mathrm{y}$; Table 1 ). Only one study recruited both children and adults [26].

The studies that were included in the systematic review had different aims: 1) Evaluation of the relationship between body composition and clinical outcomes (lung function [19,22,39,48,54], inflammation [4,21,23,45], clinical parameters [21,25-27,32], or disease severity $[28,34,36,38,47]$; and 2) validation or comparison of different techniques to evaluate the differences in body composition between patients with $\mathrm{CF}$ and healthy controls $[17,20,41,50,51,53]$ or comparison of changes in growth and/or nutritional status between subjects with and without CF $[18,33,37,42,52]$. Finally, two studies explored the association between resting energy expenditure and body composition in patients with CF (Table 1 ) $[40,49]$.

The average value from the Downs and Black quality evaluation was $8.8 \pm 2.1$. A total of 21 studies had a score $\geq 9$ and 18 


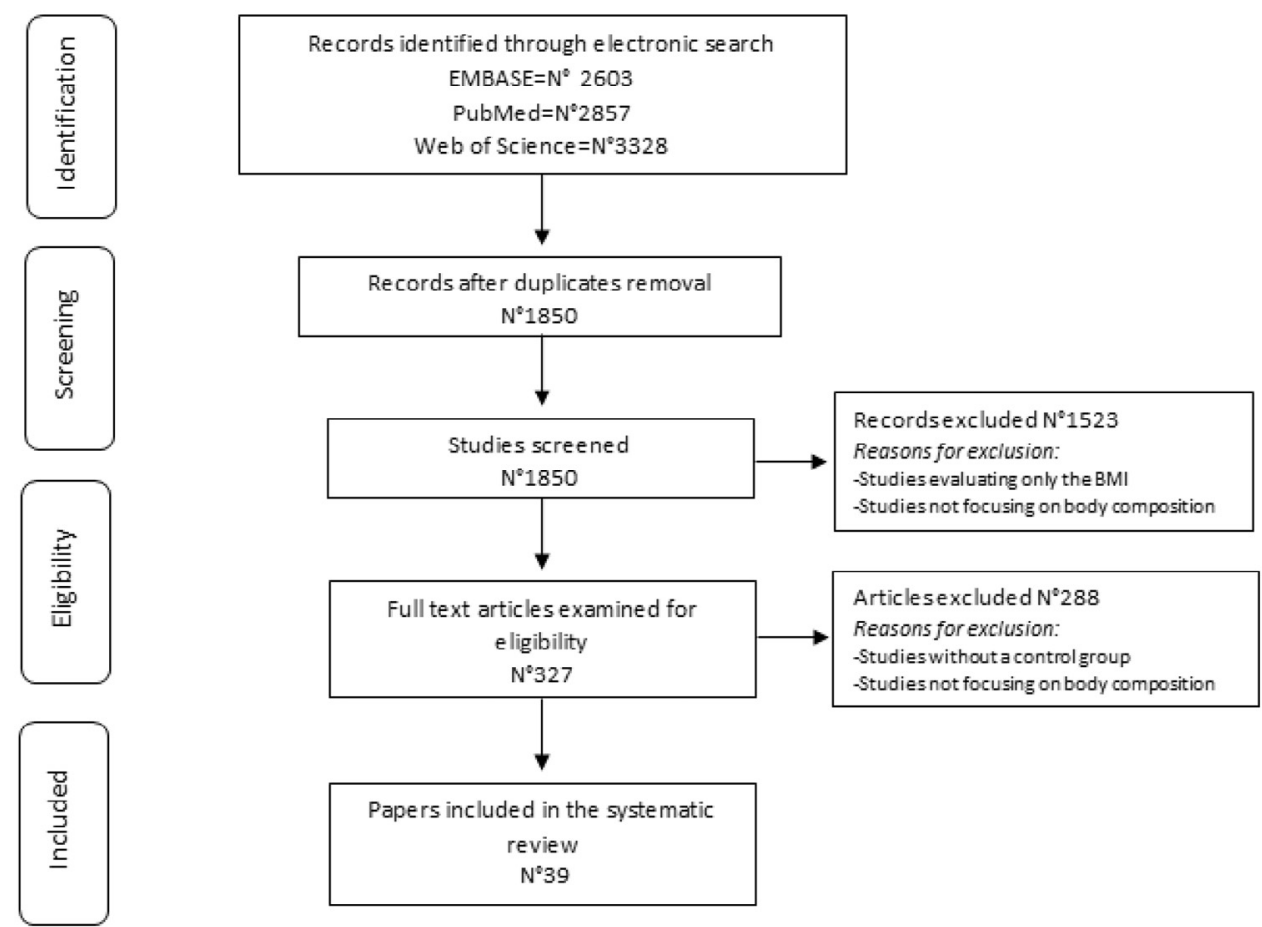

Fig. 1. Flow diagram for Preferred Reporting Items for Systematic Reviews and Meta-Analyses systematic review.

studies had a score $<9$. The minimum and maximum total scores were 5 and 12, respectively (Supplementary Table S2).

Body composition differences between subjects with and without cystic fibrosis

\section{Fat-free mass}

Six studies showed a lower FFM, lean body mass (LBM), or muscle mass in patients with CF compared with healthy subjects $[19,33,36,38,42,44]$ but four papers did not find a significant difference between the two groups $[43,45,47,52]$. Two studies in children concluded that patients with CF gained less FFM during the follow-up period than the controls [18,21] but four studies found no significant difference between the two groups $[43,45,47,52]$. A significant association was reported between low LBM, loss of diaphragm muscle mass [29], and impaired inspiratory muscle function [34]. One study also found that patients with $\mathrm{CF}$ who had low FFM were less active than those with normal FFM (Table 2) [35].

\section{Fat mass}

Four studies reported a similar FM in patients with CF compared with healthy controls $[19,36,43,45,52]$ but two studies reported a comparable FM\% in the presence of an increased central fat accumulation in patients with CF $[43,45]$. Seven studies reported a lower FM in patients with CF compared with healthy controls $[18,23,30,33,42,44,54]$, but only two of these studies were in adult populations $[30,44]$ (Table 3 ).

\section{Total body water}

Three studies measured TBW and reported that a large proportion of children with CF were considered dehydrated [22]. One study compared bioelectric impedance analysis measurements of TBW to deuterium dilution and found a significant agreement between the two methods in subjects with and without $\mathrm{CF}$ [20] but another study found that bioelectric impedance analysis overestimated TBW in patients with CF but not in controls [46] (Table 4).

Bone mineral density/content

A reduced BMD or BMC was found in patients with $\mathrm{CF}$ compared with controls: Two studies reported a low BMD at all sites (i.e., lumbar spine [L2-L4], femoral neck, Ward's triangle) [30,33] and two studies evaluated the differences of tibial and radial BMD $[25,27]$, but one study reported that hip BMD was reduced in patients with a normal BMI and low FFM [36]. Kelly et al. [37] concluded that the BMC deficit was related to an altered body size (i.e., short stature and low LBM) because the differences between patients and controls disappeared if BMC was corrected for these two variables [28]. On the other hand, three studies did not find any difference in BMD and BMC between patients with $\mathrm{CF}$ and controls who were matched for age, sex, height, and LBM [21,26,32]. All these studies used dual-energy x-ray absorptiometry or peripheral quantitative computed tomography to assess body composition (Table 5).

\section{Body composition and clinical endpoints}

\section{Respiratory function}

Thirteen studies analyzed the relationship between pulmonary function and body composition. Three studies found a higher impairment of lung function in patients with CF who had lower BMD $[35,36,39]$. Nine studies reported a significant association between low FEV $_{1}$ and low FFM or LBM $[4,19,38,43,48]$, which was exacerbated by a low BMI $[34,36]$ or poor inspiratory muscle work capacity [29]. The association between $\mathrm{FEV}_{1}$ and FM was 
Table 1

Main characteristics and aim of the of 39 studies that were selected for the systematic review

\begin{tabular}{|c|c|c|c|c|}
\hline Reference & $\begin{array}{l}\text { Study } \\
\text { design }\end{array}$ & $\begin{array}{l}\mathrm{CF} / \text { healthy } \\
\text { controls }\end{array}$ & Age (y) & Aim of the study \\
\hline Alvarez et al. [19] & Pilot CS & $32 / 20$ & $\begin{array}{l}\text { CF: } 26.1 \pm 8.9 \\
\text { C: } 30.9 \pm 8.8\end{array}$ & $\begin{array}{l}\text { Evaluate the relationship between lung function and body composition and examine the presence of } \\
\text { normal weight obesity. }\end{array}$ \\
\hline Azcue et al. [20] & CS & $20 / 21$ & $\begin{array}{l}\text { CF: } 21.2 \pm 9.1 \\
\text { C: } 21.5 \pm 8.6\end{array}$ & Validate BIA as a measure of TBW. \\
\hline Bai et al. [21] & CS & $12 / 24$ & $\begin{array}{l}\text { CF: } 11.8 \pm 0.9 \\
\text { C: } 12.4 \pm 0.9\end{array}$ & $\begin{array}{l}\text { Examine BMC and BMD and investigate geometric bone properties of children with } \mathrm{CF} \text { compared with } \\
\text { healthy controls. }\end{array}$ \\
\hline $\begin{array}{l}\text { Barbieri et al. } \\
{[22]}\end{array}$ & CS & $46 / 24$ & $\begin{array}{l}\text { CF: } 8.5 \\
\text { C: } 8.8\end{array}$ & Examine the association of nutrition and hydration status with lung function. \\
\hline $\begin{array}{l}\text { Boguszewski } \\
\text { et al. [23] }\end{array}$ & CS & $26 / 33$ & $\begin{array}{l}\text { CF: } 8.52 \pm 2.98 \\
\text { C: } 8.76 \pm 1.75\end{array}$ & $\begin{array}{l}\text { Evaluate the relationships between disease activity, body composition, IGF-1, and leptin } \\
\text { concentrations }\end{array}$ \\
\hline $\begin{array}{l}\text { Borowitz et al. } \\
{[24]}\end{array}$ & Pilot CS & $10 / 10$ & $\begin{array}{l}\text { CF: } 27 \\
\text { C: } 27.5\end{array}$ & Compare BIA to isotope dilution in patients with $\mathrm{CF}$ and control. \\
\hline $\begin{array}{l}\text { Brookes et al. } \\
{[25]}\end{array}$ & CS & $53 / 53$ & $\begin{array}{l}\text { CF: } 12.5 \pm 1.6 \\
\text { C: } 11.8 \pm 1.58\end{array}$ & Assess volumetric BMD as well as bone and muscle parameters using pQCT. \\
\hline $\begin{array}{l}\text { Buntain et al. } \\
{[26]}\end{array}$ & CS & $153 / 149$ & $\begin{array}{l}\text { CF: Range, } 5.3-55.8 \\
\text { C: Range, } 5.6-48.3\end{array}$ & $\begin{array}{l}\text { Examine the relationship between BMD and clinical parameters including physical activity, nutrition, } \\
\text { and vitamin D levels. }\end{array}$ \\
\hline $\begin{array}{l}\text { De Meer et al. } \\
\text { [17] }\end{array}$ & $\mathrm{L}$ & $26 / 13$ & $\begin{array}{l}\text { CF: } 14.7 \pm 2 \\
\text { C: } 15.2 \pm 1.9\end{array}$ & $\begin{array}{l}\text { Study applicability of the SFt method to measure changes in body composition after home exercise } \\
\text { training and assess the validity of SFt compared with DD }\end{array}$ \\
\hline $\begin{array}{l}\text { Donovan et al. } \\
\text { [27] }\end{array}$ & CS & $30 / 30$ & $\begin{array}{l}\text { CF: } 30 \pm 2 \\
\text { C: } 32 \pm 2\end{array}$ & $\begin{array}{l}\text { Examine the relationships between BMD, anthropomorphic variables, pulmonary status, } \\
\text { glucocorticoid therapy, and vitamin D concentrations. }\end{array}$ \\
\hline Elkin et al. [28] & CS & $25 / 25$ & $\begin{array}{l}\text { CF: } 28 \pm 8 \\
\text { C: } 28 \pm 7\end{array}$ & $\begin{array}{l}\text { Determine the relationship between muscle mass and strength, muscle, and bone mass and the } \\
\text { quality of CF muscle. }\end{array}$ \\
\hline Enright et al. [29] & CS & $40 / 30$ & $\begin{array}{l}\text { CF: } 22.4 \\
\text { C: } 21.7\end{array}$ & $\begin{array}{l}\text { Investigate the effect of loss of FFM on pulmonary function, physical activity, and diaphragm } \\
\text { thickness. }\end{array}$ \\
\hline Gray et al. [30] & CS & $22 / 65$ & $\begin{array}{l}\text { CF: } 23 \pm 8 \\
\text { C: } 26 \pm 6\end{array}$ & $\begin{array}{l}\text { Determine whether osteopenia occurs in adults with CF and delineate clinical and biochemical } \\
\text { predictors of BMD. }\end{array}$ \\
\hline Gruet et al. [31] & CS & $15 / 15$ & $\begin{array}{l}\text { CF: } 28 \pm 6 \\
\text { C: } 28 \pm 5\end{array}$ & $\begin{array}{l}\text { Determine whether patients with CF with mild-to-moderate lung disease have altered skeletal muscle } \\
\text { contractility and greater muscle fatigability compared with healthy controls. }\end{array}$ \\
\hline Hardin et al. [32] & CS & $\begin{array}{l}28 \text { adults, } 16 \\
\text { children } / 17 \\
\text { adults }\end{array}$ & $\begin{array}{l}\text { CF: } 25 \pm 5 \text { adults; } \\
11 \pm 1 \text { children } \\
\text { C, } 25 \pm 4 \text { adults }\end{array}$ & Measure BMD in non-acutely ill adults and BMC in children with CF. \\
\hline $\begin{array}{l}\text { Henderson and } \\
\text { Madsen [33] }\end{array}$ & CS & $47 / 40$ & $\begin{array}{l}\text { CF: } 11.9 \pm 4.0 \\
\text { C: NR }\end{array}$ & $\begin{array}{l}\text { Assess the interrelationships between various measures of growth including height, weight, and bone } \\
\text { density and the bone mineral, lean, and fat body compartments. }\end{array}$ \\
\hline $\begin{array}{l}\text { Ionescu et al. } \\
{[34]}\end{array}$ & $\begin{array}{l}\text { CS and } \\
\text { survival }\end{array}$ & $49 / 25$ & $\begin{array}{l}\text { CF: } 22.9 \pm 3.8 \\
\text { C: NR }\end{array}$ & Determine the effect of BMI and LBM depletion on handgrip force and inspiratory muscle function. \\
\hline $\begin{array}{l}\text { Ionescu et al. } \\
{[35]}\end{array}$ & CS & $22 / 22$ & $\begin{array}{l}\text { CF: } 23.6 \\
\text { C: } 23.8\end{array}$ & $\begin{array}{l}\text { Determine the relationships between host inflammatory response, body composition, bone protein } \\
\text { turnover, and catabolic status. }\end{array}$ \\
\hline Ionescu et al. [4] & CS & $40 / 22$ & $\begin{array}{l}\text { CF: } 23.1 \\
\text { C: } 23.8\end{array}$ & $\begin{array}{l}\text { Study the relationships between severity of lung disease, body composition, host inflammatory } \\
\text { response, dietary intake, and evidence of cellular and connective tissue protein breakdown. }\end{array}$ \\
\hline $\begin{array}{l}\text { Ionescu et al. } \\
{[36]}\end{array}$ & CS & $56 / 20$ & $\begin{array}{l}\text { CF: } 23 \\
\text { C: } 23.6\end{array}$ & $\begin{array}{l}\text { Determine the occurrence and distribution of hidden FFM loss and its relationship to indicators of } \\
\text { disease severity. }\end{array}$ \\
\hline Kelly et al. [37] & CS & $82 / 322$ & $\begin{array}{l}\text { CF: } 13.2 \pm 2.9 \\
\text { C: } 12.9 \pm 2.9\end{array}$ & $\begin{array}{l}\text { Characterize BMC in children with CF and determine the relationship to growth, body composition, } \\
\text { and disease severity. }\end{array}$ \\
\hline King et al. [38] & $\begin{array}{l}\text { Prospective } \\
\text { CS }\end{array}$ & $86 / 156$ & $\begin{array}{l}\text { CF: } 30.0 \pm 7.7 \\
\text { C: NR }\end{array}$ & $\begin{array}{l}\text { Determine the prevalence of FFM depletion, compare FFM index with BMI, and identify predictors of } \\
\text { FFM depletion. }\end{array}$ \\
\hline Lucidi et al. [39] & CS & $82 / 82$ & $\begin{array}{l}\text { CF: } 13.5 \pm 5.6 \\
\text { C: } 12.9 \pm 5.9\end{array}$ & $\begin{array}{l}\text { Investigate the correlation between severity of the clinical condition, bone status, and body } \\
\text { composition parameters. }\end{array}$ \\
\hline Marin et al. [40] & CS & $15 / 15$ & $\begin{array}{l}\text { CF: } 8.2 \pm 3.8 \\
\text { C, } 7.9 \pm 3.2\end{array}$ & Assess REE, nutrition status, and body composition of clinically stable outpatients with CF. \\
\hline $\begin{array}{l}\text { McNaughton } \\
\text { et al. [41] }\end{array}$ & CS & $226 / 140$ & $\begin{array}{l}\text { CF: } 8.76 \pm 5.54 \\
\text { C: NR }\end{array}$ & Compare standard anthropometric measurements and TBK as indicators of malnutrition. \\
\hline Miller et al. [42] & CS & $9 / 8$ & $\begin{array}{l}\text { CF: } 9.3 \\
\text { C: } 10.3\end{array}$ & Investigate nutritional growth retardation, body composition, and muscle protein catabolism. \\
\hline $\begin{array}{l}\text { Moriconi et al. } \\
\text { [43] }\end{array}$ & CS & $24 / 24$ & $\begin{array}{l}\text { CF: } 30.4 \pm 9.4 \\
\text { C: } 30.5 \pm 8.8\end{array}$ & $\begin{array}{l}\text { Compare body composition and serum adiponectin levels of patients with CF with those of healthy } \\
\text { controls and examine whether LBM or serum concentrations of inflammatory mediators are } \\
\text { associated with disease severity. }\end{array}$ \\
\hline Newby et al. [44] & CS & $8 / 8$ & $\begin{array}{l}\text { CF: } 27.3 \pm 3.4 \\
\text { C: } 28.4 \pm 3.5\end{array}$ & $\begin{array}{l}\text { Contrast body composition as estimated by densitometry, BIA, TOBEC, SFt, and DD of patients with CF } \\
\text { with the body composition of individuals without CF. }\end{array}$ \\
\hline $\begin{array}{l}\text { Panagopoulou } \\
\text { et al. [45] }\end{array}$ & CS & $43 / 27$ & $\begin{array}{l}\text { CF: } 20.2 \pm 8.4 \\
\text { C: } 19.9 \pm 9.4\end{array}$ & Examine serum adiponectin levels and the association with nutritional status and body composition. \\
\hline $\begin{array}{l}\text { Richards et al. } \\
{[46]}\end{array}$ & CS & $36 / 42$ & $\begin{array}{l}\text { CF: } 25.5 \pm 5.6 \\
\text { C: } 25.4 \pm 4.8\end{array}$ & $\begin{array}{l}\text { Compare the measurement of TBW by DD and BIA and determine the intraindividual differences } \\
\text { between methods for both groups. }\end{array}$ \\
\hline $\begin{array}{l}\text { Salamoni et al. } \\
{[47]}\end{array}$ & CS & $14 / 14$ & $\begin{array}{l}\text { CF: } 12.2 \pm 3.5 \\
\text { C: } 12.3 \pm 3.5\end{array}$ & Assess BMC in well-nourished patients and seek a correlation with FFM. \\
\hline Sheikh et al. [48] & CS & $208 / 390$ & $\begin{array}{l}\text { CF: } 12.4 \pm 3.85 \\
\text { C: } 11.9 \pm 3.55\end{array}$ & Assess associations of BMI and DXA-derived measures of LBM and FM with lung function. \\
\hline $\begin{array}{l}\text { Shepherd et al. } \\
\text { [49] }\end{array}$ & CS & $30 / 18$ & $\begin{array}{l}\text { CF: } 13.07 \pm 0.55 \\
\text { C: } 12.56 \pm 1.25\end{array}$ & Determine whether REE is related to either nutritional status or pulmonary function. \\
\hline Spicher et al. [50] & CS & $39 / 39$ & $\begin{array}{l}\text { CF: } 12.9 \pm 4.4 \\
\text { C: } 12.1 \pm 4.3\end{array}$ & $\begin{array}{l}\text { Compare BIA values to other values obtained by anthropometry and the urinary creatinine excretion } \\
\text { method. }\end{array}$ \\
\hline Stettler et al. [18] & $\mathrm{L}$ & $25 / 26$ & $\begin{array}{l}\text { CF: } 7.8 \pm 1.3 \\
\text { C: } 7.7 \pm 1.3\end{array}$ & $\begin{array}{l}\text { Compare changes in growth, body composition, and nutritional status between children with and } \\
\text { without CF. }\end{array}$ \\
\hline $\begin{array}{l}\text { Swisher et al. } \\
\text { [51] }\end{array}$ & Pilot CS & $10 / 10$ & $\begin{array}{l}\text { CF: } 22.2 \pm 8.5 \\
\text { C: } 21.5 \pm 2.0\end{array}$ & Compare skinfold and NIR measurements of body composition with ADP measurements. \\
\hline $\begin{array}{l}\text { Tomezsko et al. } \\
\text { [52] }\end{array}$ & CS & $23 / 24$ & $\begin{array}{l}\text { CF: } 7.8 \pm 1.3 \\
\text { C: } 7.7 \pm 1.1\end{array}$ & Compare body composition by various methods and identify patterns of growth, FFM, and FM. \\
\hline $\begin{array}{l}\text { Williams et al. } \\
\text { [53] }\end{array}$ & CS & $26 / 122$ & $\begin{array}{l}\text { CF: } 9.84 \pm 0.9 \\
\text { C: } 11 \pm 3.06\end{array}$ & Evaluate the level of agreement between DXA and the $4 \mathrm{CM}$ reference method. \\
\hline $\begin{array}{l}\text { Williams et al. } \\
\text { [54] }\end{array}$ & CS & $85 / 85$ & $\begin{array}{l}\text { CF: } 9.41 \pm 1.27 \\
\text { C: } 9.43 \pm 1.43\end{array}$ & $\begin{array}{l}\text { Compare healthy children and children with } \mathrm{CF} \text { using the } 4 \mathrm{CM} \text { and examine associations between } \\
\text { body composition and lung function. }\end{array}$ \\
\hline
\end{tabular}

4CM, four-component model; ADP, air displacement plethysmography; BIA, bioelectric impedance analysis; BMC, bone mineral content; BMD, bone mineral density; BMI, body mass index; C, controls; CF, cystic fibrosis; CS, cross-sectional design; DD, deuterium dilution; DXA, dual-energy X-ray absorptiometry; FFM, fat-free mass; FM, fat mass; L, longitudinal design; IGF-1, insulin-like growth factor 1; LBM, lean body mass; NIR, near-infrared reactance; NR, not reported; pQCT, peripheral quantitative computed tomography; REE, resting energy expenditure; SFt, skinfolds thickness; TBK, total body potassium; TBW, total body water; TOBEC, total body electrical conductivity. 
Table 2

Main findings about FFM in case-control studies on CF

\begin{tabular}{|c|c|c|c|}
\hline First author name & Techniques & Results on FFM & Main findings of the study \\
\hline $\begin{array}{l}\text { Alvarez et al. } \\
\text { [19] }\end{array}$ & ADP & $\begin{array}{l}\text { FFM index was lower in patients with } C F \text { with respect to } \\
\text { the reference group }(P<0.01) \text {. FEV } V_{1} \% \text { predicted was } \\
\text { positively associated with FFM index }(\beta=6.31 \pm 2.93 \text {; } \\
P=0.04) \text {. }\end{array}$ & $\begin{array}{l}\text { Excess adiposity, particularly in the form of NWO, was } \\
\text { inversely associated with lung function in CF. }\end{array}$ \\
\hline Bai et al. [21] & pQCT & CF group had a trend of lower LBM per height $(P<0.08)$. & \\
\hline $\begin{array}{l}\text { Boguszewski } \\
\text { et al. [23] }\end{array}$ & DXA & $\begin{array}{l}\text { Shwachman-Kulczycki score was the strongest predictor } \\
\text { of LBM. }\end{array}$ & $\begin{array}{l}\text { Children with CF remain at a high risk of malnutrition and } \\
\text { growth failure. }\end{array}$ \\
\hline $\begin{array}{l}\text { De Meer et al. } \\
{[17]}\end{array}$ & SFt & $\begin{array}{l}\text { SFt measurements are applicable to monitor FFM } \\
\text { irrespective of clinical severity of the disease. }\end{array}$ & $\begin{array}{l}\text { Repeated SFt measurements at intervals of } 6 \text { mo are applicable } \\
\text { to monitor changes in FFM during exercise training. }\end{array}$ \\
\hline Elkin et al. [28] & DXA SFt & $\begin{array}{l}\text { Both muscle strength and muscle mass (total body and } \\
\text { leg) were decreased in CF with respect to controls. }\end{array}$ & $\begin{array}{l}\text { Adults with CF are significantly weaker than controls due to } \\
\text { lower muscle mass and not to a reduced force-generating } \\
\text { capacity of the muscle. }\end{array}$ \\
\hline $\begin{array}{l}\text { Enright et al. } \\
\text { [29] }\end{array}$ & DXA & $\begin{array}{l}\text { Loss of FFM is associated with loss of diaphragm muscle } \\
\text { mass. }\end{array}$ & $\begin{array}{l}\text { There is a relationship between loss of inspiratory muscle } \\
\text { work capacity, FFM, PAS, and pulmonary function. }\end{array}$ \\
\hline $\begin{array}{l}\text { Henderson and } \\
\text { Madsen [33] }\end{array}$ & DXA SFt & LBM was reduced with a mean deficit of $11.9 \pm 2.4 \%$. & \\
\hline $\begin{array}{l}\text { Ionescu et al. } \\
\text { [35] }\end{array}$ & DXA & $\begin{array}{l}\text { Subjects with a low FFM were more catabolic and less } \\
\text { active than those with a normal FFM. }\end{array}$ & $\begin{array}{l}\text { Chronic pulmonary infection in adults with CF may be a } \\
\text { contributory factor in the long-term complications of low } \\
\text { weight and bone disease. }\end{array}$ \\
\hline $\begin{array}{l}\text { Ionescu et al. } \\
\text { [36] }\end{array}$ & BIA DXA & $\begin{array}{l}\text { Patients had a lower total FFM than healthy subjects } \\
(P<0.01) \text {. }\end{array}$ & $\begin{array}{l}\text { Hidden depletion of FFM was associated with increased loss of } \\
\text { BMD and systemic inflammatory activity. }\end{array}$ \\
\hline $\begin{array}{l}\text { Ionescu et al. } \\
\text { [34] }\end{array}$ & SFt & $\begin{array}{l}\text { There was a significant association between low LBM, } \\
\text { impaired inspiratory muscle function, and reduced HG } \\
\text { force. }\end{array}$ & $\begin{array}{l}\text { A clear relationship between body composition and } \\
\text { impairment of inspiratory muscle function was observed. }\end{array}$ \\
\hline Kelly et al. [37] & DXA & BMC deficit was related to reduced LBM. & BMC deficit was related to reduced pulmonary function. \\
\hline King et al. [38] & DXA & $\begin{array}{l}\text { FFM depletion was found in } 14 \% \text { of adults with CF but } \\
\text { undetectable by BMI in } 58 \% \text { of these patients. }\end{array}$ & One association of FFM index with $\mathrm{FEV}_{1} \%$ was found. \\
\hline Miller et al. [42] & SFt & Children with CF had a significant deficit of FFM. & $\begin{array}{l}\text { Children with } \mathrm{CF} \text { had a significant deficit of body mass } \\
(P<0.001) \text { including in muscle mass }(P<0.005) \text {. }\end{array}$ \\
\hline $\begin{array}{l}\text { Moriconi et al. } \\
\text { [43] }\end{array}$ & DXA & FFM\% was similar in patients and controls. & $\begin{array}{l}\text { Decreased LBM and increased highly sensitive C-reactive } \\
\text { protein levels were independently associated with worse lung } \\
\text { function. }\end{array}$ \\
\hline Newby et al. [44] & $\begin{array}{l}\text { BIA DD SFt } \\
\text { TOBEC UWW }\end{array}$ & $\begin{array}{l}\text { Densitometry and BIA suggested that reduced CF weights } \\
\text { were due to LBM ( } 10.7,9.5 \text {, and } 10.4 \mathrm{~kg}) \text {. TOBEC SFt and } \\
\text { DD indicated that patients with CF had less LBM than } \\
\text { controls and less fat ( } 5.4 \mathrm{~kg} \text { and } 3.6 \mathrm{~kg} \text { ) and less lean } \\
(5.2 \mathrm{~kg} \text { and } 7 \mathrm{~kg} \text { ) tissue. }\end{array}$ & $\begin{array}{l}\text { Densitometry by underwater weighing is unsuitable to assess } \\
\text { the body composition of patients with CF. }\end{array}$ \\
\hline $\begin{array}{l}\text { Panagopoulou } \\
\text { et al. [45] }\end{array}$ & BIA CT & Patients with CF and controls had comparable FFM\%. & $\begin{array}{l}\text { Patients with malnutrition tended to have a more central fat } \\
\text { distribution with increased visceral adipose tissue. }\end{array}$ \\
\hline $\begin{array}{l}\text { Salamoni et al. } \\
\text { [47] }\end{array}$ & BIA DXA & $\begin{array}{l}\text { Anthropometry, BIA, and DXA showed that FFM was } \\
\text { similar both groups. }\end{array}$ & $\begin{array}{l}\text { Bone mineral content was strongly correlated with fat-free } \\
\text { mass. }\end{array}$ \\
\hline Sheikh et al. [48] & DXA & $\begin{array}{l}\text { LBM index was more strongly associated with pulmonary } \\
\text { function than BMI (particularly in male subjects). }\end{array}$ & \\
\hline $\begin{array}{l}\text { Spicher et al. } \\
\text { [50] }\end{array}$ & BIA SFt & FFM was linearly correlated to the resistance index. & $\begin{array}{l}\text { Regression equations of BIA were similar for both patients } \\
\text { with CF and healthy subjects. }\end{array}$ \\
\hline Stettler et al. [18] & DD SFt TOBEC & $\begin{array}{l}\text { FFM increases were slower in boys with CF than in } \\
\text { controls. }\end{array}$ & $\begin{array}{l}\text { Statural growth of boys with CF was slower than that of the } \\
\text { control subjects }(P=0.004) \text { but the differences were less } \\
\text { striking for girls. }\end{array}$ \\
\hline $\begin{array}{l}\text { Tomezsko et al. } \\
\text { [52] }\end{array}$ & DD SFt TOBEC & FFM not differ significantly between the two groups. & $\begin{array}{l}\text { The majority of the methods demonstrated that the CF group } \\
\text { achieved normal growth and body composition with a } \\
\text { possible trend of fat depletion. }\end{array}$ \\
\hline
\end{tabular}

ADP, air displacement plethysmography; BIA, bioelectric impedance analysis; BMC, bone mineral content; BMD, bone mineral density; CF, cystic fibrosis; CT, computer tomography; DD, deuterium dilution; DXA, dual-energy X-ray absorptiometry; $\mathrm{FEV}_{1} \%$, forced expiratory volume in $1 \mathrm{~s}$ percentage; FFM, fat-free mass; HG, handgrip; LBM, lean body mass; NWO, normal weight obesity; SFt, skinfolds thickness; PAS, physical activity status; pQCT, peripheral quantitative computed tomography; TOBEC, total body electrical conductivity; UWW, densitometry by underwater weighing.

Shwachman-Kulczycki score to assess disease severity in CF.

examined in two studies: One study found a significant positive association in girls only [54] but the second study reported an inverse association between lung function and FM (adjusted for age, sex, and BMI) [19].

\section{Physical activity level}

Nine articles evaluated PA level using different tools such as the Wilson questionnaire [55], which was used in three studies $[30,35,36]$; Baecke questionnaire [56], which was used in two studies [31,38]; and Crocker questionnaire [57], which was used in one study [26]. One study asked parents about their child's PA level [54].
One study showed no significant correlation between PA levels and BMD [30]. One study reported a lower PA level in adults with CF than healthy controls [26] but no differences between the two groups were observed in another study [31]. The prevalence of sedentary behavior was $86.6 \%$ in patients with CF [40] and patients with less FFM were less physically active than those with normal FFM $[4,35,36]$. However, two studies reported a lack of correlation between body composition and PA level [38,54].

\section{Muscular strength}

One study tested the quadricep and hamstring isometric and isokinetic strength in adults with $\mathrm{CF}$ and matched healthy 
Table 3

Main findings about FM in case-control studies on CF

\begin{tabular}{|c|c|c|c|}
\hline First author name & Techniques & Results on FM & Main findings of the study \\
\hline $\begin{array}{l}\text { Alvarez et al. } \\
\text { [19] }\end{array}$ & ADP & $\begin{array}{l}\text { FM index and FM\% did not differ between patients with CF } \\
\text { and the reference group. } \text { FEV }_{1} \% \text { predicted was inversely } \\
\text { associated with FM index }(\beta=-6.44 \pm 2.93 ; P=0.04) \text {. }\end{array}$ & $\begin{array}{l}\text { Excess adiposity, particularly in the form of NWO, was } \\
\text { inversely associated with lung function in CF. }\end{array}$ \\
\hline $\begin{array}{l}\text { Boguszewski } \\
\text { et al. [23] }\end{array}$ & DXA & $\begin{array}{l}\text { FM standard deviation score, leptin concentration, and } \\
\text { IGF-1 SDS were lower in children with CF compared with } \\
\text { controls. }\end{array}$ & $\begin{array}{l}\text { Children with CF remain at a high risk of malnutrition and } \\
\text { growth failure. }\end{array}$ \\
\hline Gray et al. [30] & DXA & $\begin{array}{l}\text { FM was reduced by } 30 \% \text { compared with normal young } \\
\text { adults. }\end{array}$ & $\begin{array}{l}\text { BMI was positively correlated with BMD at four sites and } \\
\text { disease severity negatively correlated with BMD at two sites. }\end{array}$ \\
\hline $\begin{array}{l}\text { Henderson and } \\
\text { Madsen [33] }\end{array}$ & DXA SFt & $\begin{array}{l}\text { The deficit in FM was nearly as great, averaging } \\
18.1 \% \pm 5.3 \% \text {. }\end{array}$ & \\
\hline $\begin{array}{l}\text { Ionescu et al. } \\
{[36]}\end{array}$ & BIA DXA & Patients had similar FM as healthy subjects. & $\begin{array}{l}\text { In adults with CF, apparent or hidden loss of FFM rather than } \\
\text { weight loss was related with overall disease severity. Hidden } \\
\text { depletion of FFM was associated with increased loss of BMD } \\
\text { and systemic inflammatory activity. }\end{array}$ \\
\hline Miller et al. [42] & SFt & Children with CF had a significant deficit of FM. & $\begin{array}{l}\text { Children with } C F \text { had a significant deficit of body mass } \\
(P<0.001) \text { including muscle mass }(P<0.005) \text {. }\end{array}$ \\
\hline $\begin{array}{l}\text { Moriconi et al. } \\
{[43]}\end{array}$ & DXA & $\begin{array}{l}\text { FM\% was similar but central fat accumulation was } \\
\text { increased (trunk to extremity fat; } P=0.01 \text { ) in patients } \\
\text { compared with controls. }\end{array}$ & $\begin{array}{l}\text { Decreased LBM and increased highly sensitive C-reactive } \\
\text { protein levels were independently associated with worse lung } \\
\text { function. }\end{array}$ \\
\hline Newby et al. [44] & $\begin{array}{l}\text { BIA DD SFt } \\
\text { TOBEC UWW }\end{array}$ & $\begin{array}{l}\text { TOBEC SFt, and DD indicated that patients with CF had less } \\
\text { FM than controls. Densitometry estimates of FM were not } \\
\text { correlated }(r<0.74 ; P>0.05) \text { with any other method for } \\
\text { patients with CF but correlated with all other methods for } \\
\text { control subjects. }\end{array}$ & $\begin{array}{l}\text { Densitometry by underwater weighing is unsuitable to assess } \\
\text { the body composition of patients with CF. }\end{array}$ \\
\hline $\begin{array}{l}\text { Panagopoulou } \\
\text { et al. [45] }\end{array}$ & BIA CT & Patients with CF and controls had comparable FM\%. & $\begin{array}{l}\text { Patients with malnutrition tended to have a more central fat } \\
\text { distribution with increased visceral adipose tissue. }\end{array}$ \\
\hline Sheikh et al. [48] & DXA & FM index was not associated with pulmonary function. & \\
\hline Stettler et al. [18] & DD SFt TOBEC & FM increase was slower in boys with CF than in controls. & $\begin{array}{l}\text { Over the } 3 \text { y of the study, the statural growth of boys with } \mathrm{CF} \\
\text { was slower than that of control subjects }(P=0.004) \text {. The } \\
\text { differences in the pattern of changes in growth and body } \\
\text { composition were less striking for girls. }\end{array}$ \\
\hline $\begin{array}{l}\text { Tomezsko et al. } \\
\text { [52] }\end{array}$ & DD SFt TOBEC & $\begin{array}{l}\text { FM does not differ significantly between the two groups } \\
\text { when only using DD. FM\% differed between the groups } \\
(P<0.05) \text {. }\end{array}$ & $\begin{array}{l}\text { The majority of the methods demonstrated that the CF group } \\
\text { achieved normal growth and body composition with a } \\
\text { possible trend of fat depletion. }\end{array}$ \\
\hline $\begin{array}{l}\text { Williams et al. } \\
\text { [54] }\end{array}$ & $\begin{array}{l}\text { ADP DD DXA } \\
\text { SFt }\end{array}$ & $\begin{array}{l}\text { Girls with CF had significantly less FM than healthy girls } \\
\text { even after adjustment for height and pubertal status. }\end{array}$ & FM in girls was positively associated with $\mathrm{FEV}_{1} \%$ \\
\hline
\end{tabular}

ADP, air displacement plethysmography; BMC, bone mineral content; BMD, bone mineral density; BMI, body mass index; BIA, bioelectric impedance analysis; CF, cystic fibrosis; CT, computer tomography; DD, deuterium dilution; DXA, dual-energy X-ray absorptiometry; FEV ${ }_{1} \%$, forced expiratory volume in $1 \mathrm{~s}$ percentage; FFM, fat-free mass; IGF-1, insulin-like growth factor 1; LBM, lean body mass; NWO, normal weight obesity; pQCT, peripheral quantitative computed tomography; SDS, standard deviation scores; SFt, skinfolds thickness; TOBEC, total body electrical conductivity; UWW, densitometry by underwater weighing.

controls [28]. Patients with CF were significantly weaker than the controls due to a lower muscle mass but the force-generating capacity of the muscle appeared similar. Indices of muscle contractility appeared reduced in patients with CF compared with the controls but the difference disappeared after adjustment for muscle area, which explained a similar tolerance to fatigue in both groups [31].

\section{Mortality}

One study analyzed the association of body composition in patients with CF and mortality over a 20-mo follow-up period
[34]. The study assessed body composition using skinfolds and BMI and showed that a lower baseline BMI was associated with a greater risk of mortality.

\section{Discussion}

\section{Summary of main findings}

The majority of the studies reported significant differences in body composition (i.e., FFM, TBW, and BMD) between patients with CF and healthy controls. A consistent, significant associa-

Table 4

Main findings about TBW in case-control studies on CF

\begin{tabular}{|c|c|c|c|}
\hline First author name & Techniques & Results on TBW & Main findings of the study \\
\hline Azcue et al. [20] & $\mathrm{BIA} \mathrm{H}_{2}{ }^{18} \mathrm{O}$ & $\begin{array}{l}\text { MRA of } \mathrm{H}_{2}{ }^{18} \mathrm{O} \text { space versus anthropometric measurements } \\
\text { in both patients with } \mathrm{CF} \text { and } \mathrm{C} \text { subjects showed that } \\
\text { weight and height were significant predictors of TBW. }\end{array}$ & $\begin{array}{l}\text { The BIA predictive equation used in healthy controls } \\
\text { cannot be used for patients with } \mathrm{CF} \text {. }\end{array}$ \\
\hline Barbieri et al. [22] & BIA SFt & $\begin{array}{l}43 \% \text { of patients with } \mathrm{CF} \text { were severely/mildly dehydrated } \\
\text { but none were in the controls }(P=0.007) \text {. }\end{array}$ & $\begin{array}{l}\text { Patients with CF exhibited a compromised nutrition status } \\
\text { as assessed by anthropometric and BIA parameters that } \\
\text { were also associated with lung function. }\end{array}$ \\
\hline Richards et al. [46] & BIA DD & $\begin{array}{l}\text { TBW predicted from BIA was significantly different from } \\
\text { TBW as measured using }{ }^{2} \mathrm{H}_{2} \mathrm{O} \text { in patients with } \\
\text { CF }(P<0.05) \text { but not in controls. }\end{array}$ & $\begin{array}{l}\text { In } \mathrm{CF}, \mathrm{BIA} \text { overpredicted TBW as determined by }{ }^{2} \mathrm{H}_{2} \mathrm{O} \\
\text { dilution to an increasing extent at larger TBW volumes. }\end{array}$ \\
\hline
\end{tabular}

${ }^{2} \mathrm{H}_{2} \mathrm{O}$, heavy water; BIA, bioelectric impedance analysis; $\mathrm{C}$, controls; $\mathrm{CF}$, cystic fibrosis; DD, deuterium dilution; $\mathrm{H}_{2}{ }^{18} \mathrm{O}$, water isotope; MRA, multiple regression analysis; SFt, skinfolds thickness; TBW, total body water. 
Table 5

Main findings about BMD/BMC in case-control studies

\begin{tabular}{|c|c|c|c|}
\hline First author name & Techniques & Results on BMD/BMC & Main findings of the study \\
\hline Bai et al. [21] & $\mathrm{pQCT}$ & $\begin{array}{l}\text { Children with } \mathrm{CF} \text { have similar tBMC relative to lean mass as } \\
\text { controls. }\end{array}$ & $\begin{array}{l}\text { Cortical bone area and bone strength were less in the CF } \\
\text { group compared with controls. }\end{array}$ \\
\hline Brookes et al. [25] & pQCT & $\begin{array}{l}\text { At puberty, the CF cohort had less BMC at } 4 \% \text { tibia. Pubertal } \\
\text { female patients with } \mathrm{CF} \text { had a lower bone strength }(\mathrm{SSI}) \text { at } \\
\text { the tibia }(P=0.00) \text { and radius }(P=0.05) \text { sites. }\end{array}$ & $\begin{array}{l}\text { Bone strength parameters were not compromised before } \\
\text { puberty in this CF cohort. At puberty, several deficits were } \\
\text { present compared with the controls; however, bone } \\
\text { strength adapted to the mechanical demands of the muscle. }\end{array}$ \\
\hline Buntain et al. [26] & DXA TBK & $\begin{array}{l}\text { BMD was not significantly different in children age } 5 \text { y to } 10 \\
\text { y with CF compared with controls. }\end{array}$ & $\begin{array}{l}\text { In children/adolescents, BMD was weakly associated with } \\
\text { nutritional status and disease severity. }\end{array}$ \\
\hline Donovan et al. [27] & DXA & $\begin{array}{l}\text { Patients with CF had significantly reduced BMD at the } \\
\text { lumbar spine, total hip, and femoral neck. The radius was } \\
\text { significantly less demineralized than the other sites. }\end{array}$ & $\begin{array}{l}\text { Vertebral fractures were present in } 19 \% \text { of subjects and } 41 \% \\
\text { had a confirmed history of previous fracture. }\end{array}$ \\
\hline Elkin et al. [28] & DXA SFt & $\begin{array}{l}\text { BMD is reduced in patients with CF compared with controls. } \\
\text { When corrected for height, the differences disappeared. }\end{array}$ & $\begin{array}{l}\text { Adults with CF were significantly weaker than controls, } \\
\text { mainly due to lower muscle mass rather than a reduced } \\
\text { force-generating capacity of the muscle. }\end{array}$ \\
\hline Gray et al. [30] & DXA & $\begin{array}{l}\text { Patients with CF had significantly reduced tBMD at all sites } \\
\text { compared with normal young adults. }\end{array}$ & $\begin{array}{l}\text { BMI was positively correlated with BMD at four sites and } \\
\text { disease severity was negatively correlated with BMD at two } \\
\text { sites. }\end{array}$ \\
\hline Hardin et al. [32] & DXA & $\begin{array}{l}\text { There was no difference in tBMD and BMC between adults } \\
\text { with CF and controls matched for LBM, height, age, and sex. }\end{array}$ & $\begin{array}{l}\text { There was no correlation between pulmonary function } \\
\text { results and BMC. }\end{array}$ \\
\hline $\begin{array}{l}\text { Henderson and } \\
\text { Madsen [33] }\end{array}$ & DXA SFt & $\begin{array}{l}\text { There were significant deficits in tBMD with a mean deficit } \\
\text { of } 19.1 \pm 3.0 \% \text { in patients with CF relative to the matched } \\
\text { controls. }\end{array}$ & \\
\hline Ionescu et al. [36] & BIA DXA & $\begin{array}{l}\text { BMD at hip sites were less in patients with normal BMI and } \\
\text { low FFM compared with those with a normal BMI and FFM } \\
(\text { all } P<0.01) \text {. }\end{array}$ & $\begin{array}{l}\text { Hidden depletion of FFM was associated with increased loss } \\
\text { of BMD and systemic inflammatory activity. }\end{array}$ \\
\hline Kelly et al. [37] & DXA & BMC deficit was related to altered body size. & BMC deficit was related to reduced pulmonary function. \\
\hline
\end{tabular}

BIA, bioelectric impedance analysis; BMC, bone mineral content; BMD, bone mineral density; BMI, body mass index; CF, cystic fibrosis; DXA, dual-energy X-ray absorptiometry;FM, fat mass; FFM, fat-free mass; LBM, lean body mass; pQCT, peripheral quantitative computed tomography; SFt, skinfolds thickness; SSI, stressstrain index; TBK, total body potassium; tBMC, total bone mineral content; tBMD, total bone mineral density.

tion was found between low FFM (or LBM) and impaired respiratory function in patients with $\mathrm{CF}$. Lower PA levels and muscular strength were associated with lower LBM and associations were stronger in patients with CF compared with the controls. All studies were cross-sectional except for one longitudinal study that found a significant association between low BMI and increased risk of mortality in patients with $\mathrm{CF}$.

\section{Lean body or fat-free mass}

Dual-energy x-ray absorptiometry was the most frequently applied method to measure LBM and showed that patients with CF have a significantly reduced LBM compared with controls. This may have important diagnostic and prognostic implications in patients with $\mathrm{CF}$ at risk or with signs of malnutrition [5]. Malnutrition is commonly assessed using simple measurements such as body weight or BMI and is closely associated with impaired pulmonary function and muscle performance, which emphasize the importance of an early identification of patients at risk of malnutrition [34,58,59]. Enright et al. [29] found a significant association between low FFM in patients with CF and the severity of pulmonary disease, which was related to a loss of diaphragm muscle mass. Recent criteria by the European Society of Clinical Nutrition and Metabolism for patients with chronic obstructive pulmonary disease advocate for a more integrated diagnostic approach that combines weight loss with either ageadjusted BMI or FFM index [60]. Specifically, adults with a normal BMI and low FFM have a lower predicted $\mathrm{FEV}_{1} \%$ than adults with both normal BMI and FFM [36]. This finding underlines once again the limits of BMI as a marker of nutritional status in complex diseases such as CF [38].

Impaired pulmonary function was consistently associated with lower FFM in the studies that were included in the systematic review. Two interpretations are possible, both realistic and not mutually exclusive: 1) Patients with a worse pulmonary function and a more severe stage of the disease are characterized by a reduced appetite, which increases the risk of malnutrition and FFM loss; or 2) poor nutritional status in patients with CF may contribute to the deterioration of pulmonary function due to the inadequate performance of respiratory muscles and an increased risk of infections. However, longitudinal studies are clearly needed to clarify the relationship between FFM and pulmonary function in patients with CF.

\section{Bone health}

Studies have consistently reported a deficit of BMC and BMD in patients with CF compared with healthy controls. Factors that may affect bone health in patients with CF are still largely unknown but possible causes may include a dysregulation of the calcium-vitamin D metabolism and glucocorticoid-induced bone mobilization, which could be exacerbated by the presence of chronic inflammation.

The loss of LBM and bone could be mitigated in patients with CF by PA [61]. However, only a small number of studies that were included in this systematic review had evaluated PA levels in patients with CF. One study revealed a lower level of PA in patients with CF than controls [26] and the other three studies found that patients with CF and a lower FFM were less active $[4,35,36]$.

The relationship between BMD and physical activity was evaluated only by one study and showed no significant correlation between PA levels and BMD [30]. In addition, these studies used self-reported questionnaires to evaluate PA, which may not be entirely appropriate because they have not been validated in populations with $\mathrm{CF}$.

Finally, a recent position statement [62] highlighted this lack of evidence because no studies have evaluated physical fitness 
and exercise performance using more accurate instruments such as accelerometers or standardized exercise tests to date.

\section{Fat mass}

The evidence gathered from the systematic review was not able to provide a coherent message across the studies on the differences and roles of FM in patients with CF. The majority of the studies were conducted in children and reported a lower FM in children with CF compared with healthy controls; however, studies that were conducted in adult populations found no differences for FM between the two groups. These discrepant results could be due to differences in sample size, age, and body composition techniques that were used to evaluate FM.

Another explanation could be the energy cost of growth that may account for the reduced FM in children with CF. The energy that is expended in the synthesis of new tissues is a substantial component of the total requirement for energy (5-6 kcal/g of body weight gained), which results in large variations in growth rate and also the composition of the accrued tissue [63]. Two studies reported an increased central fat accumulation in patients with CF despite that FM\% was comparable with those of the healthy controls $[43,45]$.

\section{Limitations}

The systematic review included only studies that had a control group as part of the study design; hence, studies that evaluated body composition in patients with CF only were not included. Our primary aim was to understand the changes in body composition in patients with $\mathrm{CF}$, which could only and precisely be assessed if compared with a reference healthy group of individuals.

Finally, the large heterogeneity of the study designs, subject characteristics, and application of body composition techniques has to be taken into account for the interpretation of the results and validity of the associations between body composition and clinical outcomes.

\section{Conclusions}

Patients with CF, in this study, both adults and children, appeared to be characterized by a decrease in FFM and BMD. In addition, a decrease in FFM was consistently associated with impaired pulmonary function. The role of FM in patients with $\mathrm{CF}$ was left undefined because inconsistent results were found between the studies.

The results of the present review confirm the role of body composition in predicting the health outcomes of patients with CF. However, this evidence is predominantly from cross-sectional studies and longitudinal studies are clearly needed to provide more robust evidence on the causal associations between body composition and health outcomes in patients with CF.

\section{Supplementary data}

Supplementary data related to this article can be found at https://doi.org/10.1016/j.nut.2018.03.052.

\section{References}

[1] Cohen-Cymberknoh M, Shoseyov D, Kerem E. Managing cystic fibrosis: strategies that increase life expectancy and improve quality of life. Am J Respir Crit Care Med 2011;183:1463-71.

[2] Li L, Somerset S. Digestive system dysfunction in cystic fibrosis: challenges for nutrition therapy. Dig Liver Dis 2014;46:865-74.
[3] Ionescu AA, Nixon LS, Shale DJ. Cellular proteolysis and systemic inflammation during exacerbation in cystic fibrosis. J Cyst Fibros 2004;3:253-8.

[4] Ionescu AA, Nixon LS, Luzio S, Lewis-Jenkins V, Evans WD, Stone MD, et al. Pulmonary function, body composition, and protein catabolism in adults with cystic fibrosis. Am J Respir Crit Care Med 2002;165:495-500.

[5] Culhane S, George C, Pearo B, Spoede E. Malnutrition in cystic fibrosis: a review. Nutr Clin Pract 2013;28:676-83.

[6] Dodge JA, Turck D. Cystic fibrosis: Nutritional consequences and management. Best Pract Res Clin Gastroenterol 2006;20:531-46.

[7] Konstan MW, Butler SM, Wohl ME, Stoddard M, Matousek R, Wagener JS et al. Growth and nutritional indexes in early life predict pulmonary function in cystic fibrosis. J Pediatr 2003;142:624-30.

[8] Cystic Fibrosis Foundation. Patient registry annual data report; 2015. Available from: https://www.cff.org/our-research/cf-patient-registry/2015patient-registry-annual-data-report.pdf. [Accessed September 2017].

[9] Milla CE. Nutrition and lung disease in cystic fibrosis. Clin Chest Med 2007; 28:319-30.

[10] Corey M, McLaughlin FJ, Williams M, Levison H. A comparison of survival, growth, and pulmonary function in patients with cystic fibrosis in Boston and Toronto. J Clin Epidemiol 1988;41:583-91.

[11] Peterson ML, Jacobs DR Jr, Milla CE. Longitudinal changes in growth parameters are correlated with changes in pulmonary function in children with cystic fibrosis. Pediatrics 2003;112:588-92.

[12] Munck A. Nutritional considerations in patients with cystic fibrosis. Expert Rev Respir Med 2010;4:47-56.

[13] Turck D, Braegger CP, Colombo C, Declercq D, Morton A, Pancheva R, et al. ESPEN-ESPGHAN-ECFS guidelines on nutrition care for infants, children, and adults with cystic fibrosis. Clin Nutr 2016;35:557-77.

[14] Moher D, Liberati A, Tetzlaff J, Altman DG, Altman D, Antes G, et al. Preferred reporting items for systematic reviews and meta-analyses: the PRISMA statement (Chinese edition). J Chin Integr Med 2009;7:889-96.

[15] Downs SH, Black N. The feasibility of creating a checklist for the assessment of the methodological quality both of randomised and non-randomised studies of health care interventions. J Epidemiol Community Health 1998 52:377-84.

[16] Higgins JPT, Green S. Cochrane handbook for systematic reviews of interventions version 5.1.0 [updated March 2011]. The Cochrane Collaboration. 2011. p. Table 7.7.a.

[17] De Meer K, Gulmans VA, Westerterp KR, Houwen RH, Berger R. Skinfold measurements in children with cystic fibrosis: monitoring fat-free mass and exercise effects. Eur J Pediatr 1999;158:800-6.

[18] Stettler N, Kawachack DA, Boyle LL, Propoert KJ, Scanlin TF, Stallings VA, et al. A prospective study of body composition changes in children with cystic fibrosis. Ann N Y Acad Sci 2000;904:406-9.

[19] Alvarez JA, Ziegler TR, Millson EC, Stecenko AA. Body composition and lung function in cystic fibrosis and their association with adiposity and normalweight obesity. Nutrition 2016;32:447-52.

[20] Azcue M, Fried M, Pencharz PB. Use of bioelectrical impedance analysis to measure total body water in patients with cystic fibrosis. J Pediatr Gastroenterol Nutr 1993;16:440-5.

[21] Bai W, Binkley TL, Wallace JW, Carver TW, Specker BL. Peripheral quantitative computed tomography (pQCT) bone measurements in children with cystic fibrosis. Pediatr Pulmonol 2016;51:28-33.

[22] Hauschild DB, Barbosa E, Moreira EA, Ludwig Neto N, Platt VB, Piacentini Filho E, et al. Nutrition status parameters and hydration status by bioelectrical impedance vector analysis were associated with lung function impairment in children and adolescents with cystic fibrosis. Nutr Clin Pract 2016:31:378-86.

[23] Boguszewski MC, Kamoi TO, Bento Radominski R, Boguszewski CL, Rosberg $\mathrm{S}$, Filho NA, et al. Insulin-like growth factor-1, leptin, body composition, and clinical status interactions in children with cystic fibrosis. Horm Res 2007; 67:250-6.

[24] Borowitz K, Conboy D. Are bioelectric impedance measurements valid in patients with cystic fibrosis? J Pediatr Gastroenterol Nutr 1994;18:4536.

[25] Brookes DSK, Briody JN, Munns CF, Davies PSW, Hill RJ. Cystic fibrosisrelated bone disease in children: Examination of peripheral quantitative computed tomography (pQCT) data. J Cyst Fibros 2015;14:668-77.

[26] Buntain HM, Greer RM, Schluter PJ, Wong JC, Batch JA, Potter JM, et al. Bone mineral density in Australian children, adolescents and adults with cystic fibrosis:a controlled cross sectional study. Thorax 2004;59:149-55.

[27] Donovan DS Jr, Papadopoulos A, Staron RB, Addesso V, Schulman L, McGregor $C$, et al. Bone mass and vitamin D deficiency in adults with advanced cystic fibrosis lung disease. Am J Respir Crit Care Med 1998;157:1892-9.

[28] Elkin SL, Williams L, Moore M, Hodson ME, Rutherford OM. Relationship of skeletal muscle mass, muscle strength and bone mineral density in adults with cystic fibrosis. Clin Sci 2000;99:309-14.

[29] Enright S, Chatham K, Ionescu AA, Unnithan VB, Shale DJ. The influence of body composition on respiratory muscle, lung function and diaphragm thickness in adults with cystic fibrosis. J Cyst Fibros 2007:6:384-90.

[30] Grey AB, Ames RW, Matthews RD, Reid IR. Bone mineral density and body composition in adult patients with cystic fibrosis. Thorax 1993;48:58993. 
[31] Gruet M, Decorte N, Mely L, Vallier JM, Camara B, Quetant S, et al. Skeletal muscle contractility and fatigability in adults with cystic fibrosis. J Cyst Fibros 2016;15:e1-8.

[32] Hardin DS, Arumugam R, Seilheimer DK, LeBlanc A. Normal bone mineral density in cystic fibrosis. Arch Dis Child 2001;84:363-8.

[33] Henderson RC, Madsen CD. Bone mineral content and body composition in children and young adults with cystic fibrosis. Pediatr Pulmonol 1999;27: 80-4.

[34] Ionescu AA, Chatham K, Davies CA, Nixon LS, Enright S, Shale DJ. Inspiratory muscle function and body composition in cystic fibrosis. Am J Respir Crit Care Med 1998;158:1271-6.

[35] Ionescu AA, Nixon LS, Evans WD, Stone MD, Lewis-Jenkins V, Chatham K, et al. Bone density, body composition, and inflammatory status in cystic fibrosis. Am J Respir Crit Care Med 2000;162:789-94.

[36] Ionescu AA, Evans WD, Pettit RJ, Nixon LS, Stone MD, Shale DJ. Hidden depletion of fat-free mass and bone mineral density in adults with cystic fibrosis. Chest 2003;124:2220-8.

[37] Kelly A, Schall JI, Stallings VA, Zemel BS. Deficits in bone mineral content in children and adolescents with cystic fibrosis are related to height deficits. J Clin Densitom 2008;11:581-9.

[38] King SJ, Nyulasi IB, Strauss BJG, Kotsimbos T, Bailey M, Wilson JW. Fat-free mass depletion in cystic fibrosis: Associated with lung disease severity but poorly detected by body mass index. Nutrition 2010;26:753-9.

[39] Lucidi V, Bizzarri C, Alghisi F, Bella S, Russo B, Ubertini G, et al. Bone and body composition analyzed by dual-energy x-ray absorptiometry (DXA) in clinical and nutritional evaluation of young patients with cystic fibrosis: a cross-sectional study. BMC Pediatr 2009;9:61.

[40] Marín VB, Velandia S, Hunter B, Gattas V, Fieldbaum O, Herrara O, et al. Energy expenditure, nutrition status, and body composition in children with cystic fibrosis. Nutrition 2004;20:181-6.

[41] McNaughton SA, Shepherd RW, Greer RG, Cleghorn GJ, Thomas BJ. Nutritional status of children with cystic fibrosis measured by total body potassium as a marker of body cell mass: Lack of sensitivity of anthropometric measures. J Pediatr 2000;136:188-94.

[42] Miller M, Ward L, Thomas BJ, Cooksley WG, Shepherd RW. Altered body composition and muscle protein degradation in nutritionally growth-retarded children with cystic fibrosis. Am J Clin Nutr 1982;36:492-9.

[43] Moriconi N, Kraenzlin M, Muller B, Keller U, Nusbaumer CP, Stohr S, et al. Body composition and adiponectin serum concentrations in adult patients with cystic fibrosis. J Clin Endocrinol Metab 2006;91:1586-90.

[44] Newby MJ, Keim NL, Brown DL. Body composition of adult cystic fibrosis patients and control subjects as determined by densitometry, bioelectrical impedance, total-body electrical conductivity, skinfold measurements, and deuterium oxide dilution. Am J Clin Nutr 1990;52:209-13.

[45] Panagopoulou P, Fotoulaki M, Manolitsas A, Pavlitou-Tsiontsi E, Tsitouridis I, Nousia-Arvanitakis S. Adiponectin and body composition in cystic fibrosis. J Cyst Fibros 2008; 7:244-51.

[46] Richards ML, Bell SC, Edmiston KA, Davies PSW. Assessment of bioelectrical impedance analysis for the prediction of total body water in cystic fibrosis. Asia Pac J Clin Nutr 2003;12:161-5.

[47] Salamoni F, Roulet M, Gudinchet F, Pilet M, Thiebaud D, Burckhardt P. Bone mineral content in cystic fibrosis patients: Correlation with fat-free mass. Arch Dis Child 1996;74:314-18.
[48] Sheikh S, Zemel BS, Stallings VA, Rubenstein RC, Kelly A. Body composition and pulmonary function in cystic fibrosis. Front Pediatr 2014;2:1-7.

[49] Shepherd RW, Greer RM, McNaughton SA, Wotton M, Cleghorn GJ. Energy expenditure and the body cell mass in cystic fibrosis. Nutrition 2001;17:225.

[50] Spicher V, Roulet M, Schaffner C, Schutz Y. Bio-electrical impedance analysis for estimation of fat-free mass and muscle mass in cystic fibrosis patients. Eur J Pediatr 1993;152:222-5.

[51] Swisher AK, Yeater R, Moffett K, Baer L, Stanton B. A comparison of methods to determine body fat in individuals with cystic fibrosis: a pilot study. J Exerc Physiol 2003;6:105-14.

[52] Tomezsko JL, Scanlin TF, Stallings VA. Body composition of children with cystic fibrosis with mild clinical manifestations compared with normal children. Am J Clin Nutr 1994;59:123-8.

[53] Williams J, Wells J, Wilson C, Haroun D, Lucas A, Fewtrell M. Evaluation of lunar prodigy dual-energy $\mathrm{x}$-ray absorptiometry for assessing body composition in healthy individuals and patients by comparison with the fourcomponent model. Am J Clin Nutr 2005;68:1047-54.

[54] Williams JE, Wells JC, Benden C, Jaffe A, Suri R, Wilson CM, et al. Body composition assessed by the 4-component model and association with lung function in 6-12-y-old children with cystic fibrosis. Am J Clin Nutr 2010;92: 1332-43.

[55] Wilson PWF, Paffenbarger RS Jr, Morris JN, Havlik RJ. Assessment methods for physical activity and physical fitness in population studies: report of a NHLBI workshop. Am Heart J 1986;111:1177-92.

[56] Baecke JAH, Burema J, Frijters JER. A short questionnaire for the measurement of habitual physical activity in epidemiological studies. Am J Clin Nutr 1982;36:936-42.

[57] Crocker PR, Bailey DA, Faulkner RA, Kowalski KC, McGrath R. Measuring general levels of physical activity: preliminary evidence for the Physical Activity Questionnaire for Older Children. Med Sci Sports Exerc 1997;29:13449.

[58] Zemel BS, Jawad AF, Fitzsimmons S, Stallings VA. Longitudinal relationship among growth, nutritional status, and pulmonary function in children with cystic fibrosis:analysis of the Cystic Fibrosis Foundation National CF Patient Registry. J Pediatr 2000;137:374-80.

[59] Hollander FM, De Roos NM, De Vries JHM, Van Berkhout FT. Assessment of nutritional status in adult patients with cystic fibrosis: whole-body bioimpedance vs body mass index, skinfolds, and leg-to-leg bioimpedance. J Am Diet Assoc 2005; 105:549-55.

[60] Ingadottir AR, Beck AM, Baldwin C, Weekes CE, Geirsdottir OG, Ramel A, et al. Two components of the new ESPEN diagnostic criteria for malnutrition are independent predictors of lung function in hospitalized patients with chronic obstructive pulmonary disease (COPD). Clin Nutr 2017; doi:10.1016/ j.clnu.2017.05.031.

[61] Daly RM. Exercise and nutritional approaches to prevent frail bones, falls and fractures: an update. Climacteric 2017;20:119-24.

[62] Bradley J, O’Neill B, Kent L, Hulzebos EH, Arets B, Hebestreit H, et al. Physical activity assessment in cystic fibrosis: a position statement. J Cyst Fibros 2015;14:e25-32.

[63] Fjeld CR, Schoeller DA, Brown KH. A new model for predicting energy requirements of children during catch-up growth developed using doubly labeled water. Pediatr Res 1989;25:503-8. 